\title{
Agricultural Land Use Planning and Groundwater Quality
}

\author{
ROBERT L. FERRETT \\ ROBERT M. WARD
}

$\mathbf{J}$ AN McHARG has provided a method of study that has been adopted by many rural land use planners. In his well-known work, Design with Nature, individual elements of the environment are depicted on maps, and these are overlaid to determine future land uses that are best suited to specific geographical areas. ${ }^{1}$ In some instances, whether a particular land use conflicts with the physical limitations of the land may not be clear. Such is the case when agricultural use is being planned for areas of groundwater recharge (the replenishment of aquifers through percolation of surface water). The uncertainty pertains specifically to the potential for undesirable chemical compounds from fertilizers, herbicides, pesticides, and animal wastes to infiltrate aquifers that serve as a source of water for human consumption.

Groundwater reservoirs, commonly known as aquifers, provide about 45 percent of the drinking water consumed in the United States. ${ }^{2}$ The aquifers were once thought to hold water of limitless quantity and uniform. ly excellent quality. Recently, however, many chemicals have been found contaminating these reservoirs. Most areas of the United States, including Puerto Rico, are experiencing significant groundwater pollution (Figure 1). From reports received from each of the 10 U.S. Environmental Protection Agency (EPA) regional administrators, the Council on Environmental Quality compiled information on the geographic distribution of groundwater and drinking water contamination by toxic organic chemicals. Data from 34 states indicate major problems. $^{3}$ The area least affected, as illustrated in Figure 1, is in the Northwest. Even the relatively nonindustrial and sparsely populated state of New Mexico has cause for concern. While the sources of these pollutants are debated, agricultural lands are coming under close scrutiny by regional, state, and national officials. Although runoff from farm areas has been a

Robert L. Ferrett previously served as a science advisor for the Michigan legislature. He presently runs his own consulting firm, Entech Consultants of Ann Arbor, Michigan. Robert M. Ward, professor of geography at Eastern Michigan University, specializes in rural land use planning. major problem which has received considerable attention and many methods are already in use to try to control it, the effects of agricultural contaminants percolating into groundwater have received less investigation. This is somewhat paradoxical because farms are the major consumers of groundwater in the United States.

Although several agricultural experiment stations and land grant universities have examined the problem of farm pollutants entering aquifers, these studies have not been included in applied social science journals. This paper will examine various chemicals used by agriculturalists and their effects on groundwater quality to determine whether land use restrictions should be considered to limit pollution from percolating water. Several possible actions used to minimize damage to groundwater quality will be noted. The latter portion of the paper contains a summary of federal and state legislative action directed toward protecting groundwater resources. Although this report can provide guidance for land use planners, the uniqueness of all areas necessitates on-site appraisals to determine specific impacts on groundwater quality.

\section{Agricultural Pollutants}

The pollution of groundwater comes from both point and nonpoint sources. Point sources-for example, industrial discharges, municipal sewage treatment plants, landfills, and sewer overflows-have received much attention. Nonpoint sources of pollution, which have been a more recent concern, include urban runoff, construction projects, hydrological modification, silviculture (tree farming), mining, agriculture, irrigation return flows, and individual sewage disposal. Urban runoff is the major cause of pollution in most municipal water supplies. Agricultural sources are the largest cause of pollution in all other areas, but they are probably the least under. stood. ${ }^{4}$

Fertilizers are composed basically of nitrogen, phosphorus, and potassium. Among these, only nitrogen and phosphorus are potentially significant agricultural pollutants of groundwater. Nitrogen, no matter in what form it is applied initially, eventually is converted into nitrate under aerobic conditions. Nitrates are water soluble and 
FIGURE 1. GROUNDWATER POLLUTION PROBLEMS, AS IDENTIFIED BY FEDERAL, STATE, AND REGIONAL STUDY TEAMS

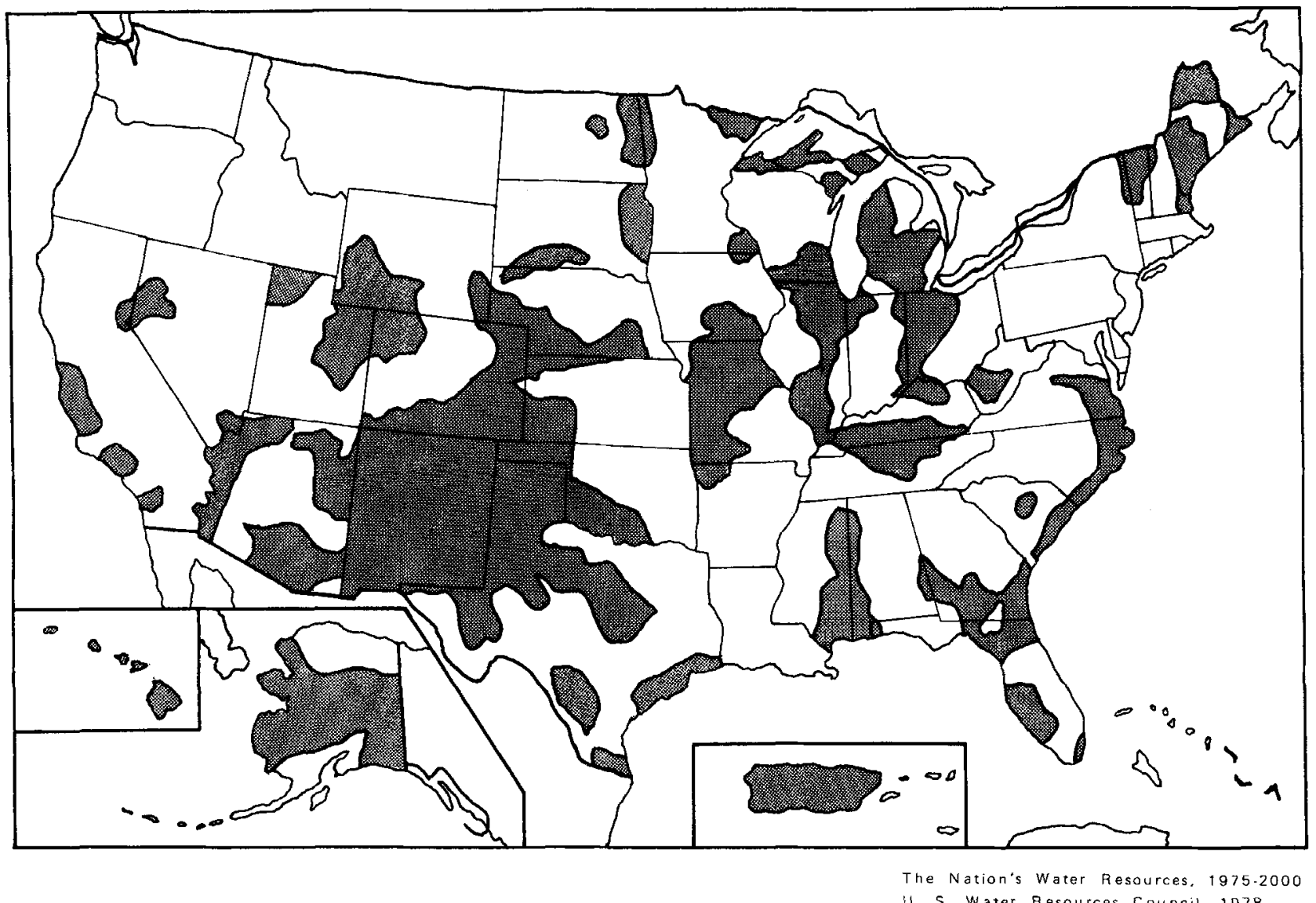

can flow freely into aquifers. ${ }^{5}$ High concentrations of nitrates cause accelerated algal growth, which is the initial stage of stream or lake eutrophication. Between 40 and 80 percent of all nitrogen applied to the soil is consumed by crops. ${ }^{6}$ Denitrification and volatilization result in atmospheric release of part of the remainder, although the exact amount is difficult to ascertain because of differences in soil types, temperatures, and moisture and organic contents. Generally, denitrification proceeds much more rapidly in warm soil than in cold and in saturated soils than in dry. An important factor in denitrification is the amount of organic matter in the ground; higher organic levels result in higher rates of denitrification. In areas of moderate temperatures and medium soil textures, about half of the remaining nitrogen will be released due to denitrification. From 10 to 30 percent of the applied nitrogen leaches into aquifers. $^{7}$

Nitrogen leaching can be kept to a minimum through several management techniques. These include adjusting seasonal applications to soil, moisture, and temperature conditions; adjusting the application to crop needs instead of indiscriminately overfertilizing; educating fertilizer users; and adding bactericides to inhibit nitrate production. ${ }^{8}$ All of the above can be carried out by individual users with the aid of farm agencies. Help in reducing fertilizer usage should be especially welcome to farmers because the cost of nitrogen products is increasing rapidly.

Phosphates are also applied as fertilizer, although not in quantities as large as nitrogen. Phosphates are moderately soluble and do not move as rapidly in groundwater as nitrates. ${ }^{9}$ Phosphate compounds seldom percolate into groundwater because they are less soluble and adsorb readily onto soil particles. While such adsorption poses a sizable risk to surface water because adsorbed phosphates may be transported on runoff sediment, it poses a negligible threat to groundwater except in areas with water tables very close to the surface.

The control chemicals, such as pesticides, herbicides, and fungicides, vary widely in solubility, adsorptive characteristics, toxicity levels, and breakdown time. Chlorinated hydrocarbons are a large group of pesticides which can pose major threats to the environment. They 
are readily assimilated by aquatic animals, are fat soluble, and thus enter the food chain. Most chlorinated hydrocarbon pesticides, however, are readily adsorbed at the surface by clay and organic matter. They have very low water solubility and are thus more of a threat to surface water through runoff than they are to groundwater, unless the groundwater is very close to the surface. The adsorbed chlorinated hydrocarbons are generally decomposed by bacteria. ${ }^{10}$ These pesticides are also volatilized and degraded by ultraviolet light. ${ }^{11}$

Another major group of pesticides which has become increasingly popular recently are organophosphates. These are the most toxic of the pesticides, both to insects and to animals. Most organophosphates are biodegraded much more quickly than the chlorinated hydrocarbons. Although great care must be taken in their application, they are not very persistent in the environment and do not appear to pose a threat to groundwater. ${ }^{12}$

The third major group of pesticides is the carbamates. These are very broad-spectrum insecticides and are of a relatively low toxicity level. The carbamates probably do not seriously harm groundwater supplies because of their low toxicity and relatively rapid decomposition. ${ }^{13}$

Those persistent pesticides which have extremely long half-lives, such as DDT, chlordane, lindane, and aldrin, have been restricted by the Environmental Protection Agency. ${ }^{14}$ The recent introduction of more water-soluble pesticides may be a cause for concern. However, the amounts used are far less than those of the chlorinated hydrocarbons or organophosphates, and these new pesticides do not persist in the soil very long. These must be used cautiously to avoid excessive and improper applications. Furthermore, care should be used in areas with high water tables.

Herbicides are also widely used in agriculture. These generally have lighter molecular weights than pesticides and are somewhat more water-soluble. Although exact percentages are not known, some of the unused herbicides are volatilized into the atmosphere, some are metabolized by plants, and others are biodegraded at or near the ground surface by microorganisms. Although these chemicals will percolate downward with water, most herbicides can be broken down under anaerobic conditions. The chemical decomposition does not cease in the deeper soils where oxygen is of low concentration. ${ }^{15}$ Herbicides such as fluometuron have been field tested using 10 times the needed amount and have been found as deep as four feet, although in small concentrations of less than 0.5 parts per million. These small quantities appear to have broken down after reaching the water table. ${ }^{16}$ While herbicides do not pose as great a threat to surface water as pesticides, they have a greater likelihood of entering the groundwater through percola- tion. Thus, even greater caution is advised where use is considered on lands with a water table within 10 feet of the surface. The relatively low toxicity levels of most herbicides and their rapid decomposition minimize their effects on groundwater. ${ }^{17}$

Fungicides, the third major group of control chemicals, are also applied extensively to agricultural lands. There are two categories of fungicides: organic and inorganic. The organic fungicides generally have very short half-lives, lasting from a few hours to a few weeks. Nearly all of these biodegrade rapidly and pose little threat to groundwater. A few, such as quintozene, are more persistent but again degrade in the soil unless the water table is very high. ${ }^{18}$ The use of these longer-lived fungicides is declining. The inorganic fungicides can pose more serious environmental problems because of their metal bases, such as copper, mercury, or arsenic, and because of their persistence for many years in the soil. These chemicals are not biodegradable, but they do adsorb to clay and organic matter in the ground. This adsorption causes problems with runoff, but the adsorbed metals seldom reach the groundwater and do not migrate rapidly when they do. Fortunately, the use of inorganic fungicides has declined in recent years.

Animal waste also contributes to groundwater contamination. Such wastes are of two forms: nutrients and bacteria. Nitrogen levels in animal waste can be relatively high. Where wastes are kept in confined areas such as feedlots, manure piles, or waste treatment lagoons, nitrate leaching is particularly evident. Investigators who conducted field studies in Colorado concluded that nitrate passed through the soil into groundwater under surfaces covered by feedlots and irrigated fields. ${ }^{19}$ Only in irrigated fields of alfalfa were nitrate concentrations reduced in the soil profile.

Reports with conflicting conclusions emphasize the importance of examining local environmental conditions and agricultural practices carefully. Another empirical investigation in Colorado was performed in an area before 90,000 cattle were confined in a feedlot and again after the lot was stocked. ${ }^{20}$ It was determined that few water quality changes occurred after the cattle were confined. This was attributed to limited availability of recharge, relatively compact manure, denitrification in the unsaturated soil zone, and slow vertical movements of leachate.

Mielke and Ellis stated, "Feedlots should not pose a threat to regional groundwater quality in areas of glacial till and alluvial or loess deposits, since once a feedlot has been established and continuously stocked, nutrient seems to move slowly in the soil profile." 13 They further expressed concern about seasonally empty or abandoned feedlots, especially on clayey soils, where drying causes soil to crack and allows infiltration of 
waste nutrients. In these instances groundwater quality can be affected negatively. Again, these investigators noted the importance of planting alfalfa in abandoned feedlots to reduce the likelihood of nitrates reaching the water table.

Regularly cleaned feedlots tend to cause more of a problem than ones which have accumulated waste products. Regular cleaning promotes nitrification. An accumulation of waste material generally results in anaerobic soil conditions; however the resulting change in the $\mathrm{pH}$ level due to ammonia build-up causes some ammonia volatilization. The unvolatilized ammonia adsorbs to the soil and reduces the amount of nitrogen that will percolate. ${ }^{2}$ Nitrate leaching can also be avoided by paving feedlots and storing waste in watertight structures for future processing.

Bacterial pollution of groundwater does exist in agricultural areas although it is not recognized as a major waste problem. Most bacteria reaching the groundwater from animal waste are fecal coliform bacteria, yet small quantities of streptococcal bacteria and other pathogens can be present. While coliform bacteria are not considered harmful to humans, high bacteria counts do indicate the possible presence of pathogens which can pose a health threat. Leaching of these bacteria can be controlled using the watertight lagoons mentioned previously or by spreading the waste thinly on the ground. By far the most common form of bacterial pollution of water comes from runoff.

\section{Discussion}

The question that arises for planners is whether the threat of undesirable chemicals entering groundwater recharge areas is serious enough to require land use restrictions, or whether better management practices and education can keep the problems at a tolerable level. Although the answer remains somewhat elusive, there is no doubt that the identification of recharge areas and restrictions on the use of these lands would lower contamination through percolation. A total ban on any type of farming activity would halt the problems in these areas. Less-than-total restriction, such as allowing only grazing or light farming with no nutrient or pest control, would also reduce groundwater pollution. However, there are many problems with these approaches. Identification of some recharge areas may be difficult to achieve. Once they have been mapped, attempts to halt individuals from farming these lands would probably meet with widespread resistance by farmers, farm organizations, and local governments that depend on this land for a tax base.

A much more serious land use problem would arise if these obstacles were cleared. Many of the recharge areas and the immediately surrounding areas are also prime agricultural lands. The loss of the best agricultural land in this country is already a major concern. Restricting intensive farming on recharge areas would greatly exacerbate this situation. One program proposed recently recognized these problems. ${ }^{23}$ The proposal suggested identification of "critical recharge areas" and, through regulatory agencies, rezoning and restriction of landfill uses, manufacturing, road development, and residential and commercial development. No attempts would be made to restrict agricultural use, even though ideally this total protection of recharge areas implies preservation of the area in its natural vegetated state.

If land use restrictions are not the answer to nutrient control and animal waste pollution, alternatives must be found to alleviate these problems. Nutrient overuse and misuse will be partially solved economically. With the continuously increasing cost of nitrogen and phosphorus compounds, most users will be forced to use more rational application techniques. At that time, farmers will reconsider their application program and seek advice which will help control excessive nutrient use.

Technical assistance would also benefit the users of control chemicals. Scientific advances and manufacture of more selective strains of these chemicals with shorter half-lives are already reducing pollution. Because relatively small amounts of these chemicals percolate into the groundwater, as discussed earlier, control chemicals will seldom pose a severe threat to the groundwater.

Animal wastes from large feedlots can be handled with a minimum of problems by using water-tight storage areas and lagoons under anaerobic conditions. These wastes can then be reprocessed and applied to the land as fertilizer or converted into methane. Roofed feedlots and deflection of surface runoff from waste collection areas will also lessen the problem of pollution from percolation. Waste from large grazing areas is not as great a problem, especially when these lands are planted with alfalfa, but some contaminants, particularly nitrates, will leach into aquifers. This is a problem for which there is no complete solution, but it is also only a very small part of the overall pollution profile.

\section{Status of Legislative Action}

Although groundwater contamination by agricultural activities is not generally viewed as constituting a significant problem, there are localized instances in which this situation may become very detrimental. Where surface and subsurface conditions contribute to rapid nitrification and do not inhibit downward movement of harmful contaminants, steps should be initiated to ameliorate the condition. This is especially true in a sole-source rural water supply area. Two actions can be taken: (1) 
receiving voluntary commitments from agriculturalists to change their management practices, and (2) legislating land use controls that protect critical recharge areas.

While it appears impossible to expect water to return to a pristine state, there is no cause to be satisfied with water that is hazardous to human health and welfare. Voluntary contraints on the part of the public have been inadequate. Groundwater contamination continues to render some supplies unfit for human consumption. In other cases, contamination has limited the water usability for agriculture and industry.

According to Hurd,

There is no Federal statute devoted solely to groundwater concerns, no Federal program exclusively devoted to problems unique to the groundwaters, and no national groundwater policy. Rather, there exist fragmented authorities whose implementing responsibilities are divided among various Environmental Protection Agency water and water-related programs. ${ }^{24}$

Hurd cites six federal statutes that directly relate to groundwater: the Clean Water Act, the Safe Drinking Water Act, the Resources Conservation and Recovery Act, the Toxic Substances Control Act, the National Environmental Protection Act, and the Federal Insecticide, Fungicide, and Rodenticide Act. It is the contention of Hurd, an EPA representative, that adequate authority is contained in these acts to allow the federal government to fulfill its role in groundwater protection. Conversely, it may be argued that because no one, comprehensive federal law exists to protect groundwater, the total reliance on federal statutes might not be justified. $^{25}$ The immediate tasks of federal authorities appear to center on coordinating their various programs to achieve effective groundwater quality and to produce legislation that solely addresses the problem of groundwater quality.

One of the more pertinent sections of federal legislation pertaining to recharge zones is 1424 (e) of the Safe Drinking Water Act. This section allows EPA administrators to designate an aquifer as the sole or principal source of drinking water for a region and thus uses protection of the recharge zone as a method of groundwater management. ${ }^{26}$ Such designation may result from a petition or from an internal EPA recommendation. The basis of such protection is that because an area relies on water from a sole or principal source its pollution would create a significant hazard to public health. The law specifies that no federal financial assistance will be given to any project in the recharge zone that the EPA believes would have a detrimental impact on public health from groundwater contamination. ${ }^{27}$ Section 1424 (e) has been used sparingly and is the only federal regulation to use recharge zone protection to achieve groundwater management.

An example of a more widely used technique of the federal government for groundwater planning is contained in the Clean Water Act, Pub.L. 92-500, section 208. This legislation advocates a planned approach to protecting water quality, yet it has not substantially affected groundwater quality. Arguments have been advanced that cite 208's emphasis on surface water and only implied action on groundwater issues. In some instances, a benefit to surface water may have a negative impact on groundwater. Because the emphasis of 208 is on landfills and the treatment of wastes, it can be expected to produce an increasing number of groundwater-polluting sources. ${ }^{28}$ Section 208 contains the only Clean Water Act requirements for nonpoint source control. $^{29}$ Although the act recognizes persistent problems in the treatment of surface water, history has revealed only limited success in resolving nonpoint source contamination of surface waters. Groundwater pollution presents an even more difficult management situation; consequently it is unlikely that section 208 can be relied upon to make major improvements in groundwater resources.

During late 1980, the Environmental Protection Agency proposed a plan to act as a framework for all of its efforts to protect groundwater. The proposal emphasized management approaches, summarized existing federal and state legislation, and recommended a closer interaction between the two levels of government. This initiative seems to have been ignored by President Reagan's administrator of the EPA even though she has been urged by environmentally conscious congressional representatives to act on the two-year-old proposal. ${ }^{30}$ This neglect has effectively forced state agencies to assume responsibility for managing groundwater quality.

Two extensive surveys of state groundwater programs, statutes, and regulations have been conducted using input from appropriate representatives of the 50 states. It was learned that most of the state agencies involved with regulating groundwater quality operated under a general environmental law governing pollution of "water of the state." As in Minnesota's Environmental Protection Law, protected water generally includes

all streams, lakes, ponds, marshes, watercourses, waterways, wells, springs, reservoirs, aquifers, irrigation systems, drainage systems, and all other bodies and accumulations of water, surface and underground, natural and artificial, public or private, which are contained within, flow through, or border upon, the State or any portion thereof. ${ }^{31}$

Bartelt's survey, conducted by his Ground-Water Protection Section (EPA, Region 5), cited only Georgia, Utah, 
and Virginia as having specific groundwater laws. ${ }^{32}$ Dawson's survey, conducted for the Virginia State Water Control Board, showed that respondents in all three of these states noted deficiencies in the legislation. ${ }^{33}$

Even though states have not enacted responsible groundwater legislation, they and local governments are logical sources to develop groundwater quality plans and establish implementation and enforcement of standards. State and local officials must decide what activities will be allowed to occupy the sites of important recharge areas. The Texas Water Control Board, for example, prohibited animal feedlot operations in a sole-source recharge zone of the Edwards Aquifer. High-density residential usages, hazardous industrial development, large commercial activities, large-area transportation facilities, and sanitary/toxic landfills should be excluded from primary recharge areas. Although several limitations exist on local and state legislative abilities, zoning, permits, and similar land use regulations to prevent groundwater contamination are legitimate uses of police power and have been widely supported by the courts. ${ }^{34}$

Dade County (Miami), Florida, exemplifies a local government that has effectively responded to potential groundwater contamination. To assure future quality of both surface water and groundwater, the County Metropolitan Planning Organization compiled the "Recommended Management Plan for the East Everglades." Developed in $1979-80$ with the help of the United States Geological Survey and the Everglades National Park staff, the plan was funded by the EPA and several state and local organizations and approved by the County Commission in November 1980. Additional ordinances recognize a large area west of Miami as an "area of critical environmental concern" and establish overlay zoning regulations and a severable use rights program. ${ }^{35}$

The East Everglades area consists of many types and usages of land, including swamp, agricultural, residential, and commercial. The plan recognizes that "the protection of agriculture as a viable enterprise is an explicit goal... and the lands identified for agricultural use ... are vital to the health, safety and welfare of the present and future residents of Dade County, Florida."36 The zoning regulations include protection of both surface water and groundwater. Lot sizes and land usage are severely restricted. Agriculture is prohibited in certain critical recharge zones, ditching is regulated on farms, and structure concentrations and lot sizes are regulated. Even infiltration rates are regulated by mandatory use of on-site retention techniques.

Establishing quality standards for groundwater is fundamental to control of the problem. ${ }^{37}$ These standards should be implemented at a level that would allow all people to have safe water to drink. Although the goal is admirable, it will not be attained easily. Initially an acceptable level of contamination must be identified. Although scientists can provide input, in the final analysis, legislators must make value judgments to determine legal levels. As Paracelsus (1493-1541) once stated, "All substances are poison; there is none which is not a poison. The right dose differentiates a poison and a remedy." If we accept the validity of this statement, then we must be resigned to talk about substances that are more or less toxic.

While groundwater quality standards are debated, base data need to be gathered. It is difficult to differentiate between agriculturally produced contaminants and those occurring naturally from decomposition of rock and organic matter. Without this knowledge, changes in groundwater quality cannot be measured. The development of such data not only requires sampling but also necessitates a thorough understanding of water recharge zones and aquifer systems. Currently, this detailed information is available only in limited areas. It will also be necessary to determine what constitutes a significant change in quality and how responsibility for the change is to be assigned.

Monitoring must be one of the main components of a groundwater management program, but the inherent problems may be so complex that it may be nearly impossible to assign legal liability for contamination..$^{38}$ In addition, the creation of an adequate monitoring program is hampered by fiscal realities. The state of Michigan illustrates these realities:

The most serious obstacle to responding to contaminated sites and implementing groundwater protection strategies is the lack of sufficient resources. For example, equipment is required to drill groundwater monitoring wells. Currently, the Michigan Department of Natural Resources has one well drilling rig and has only limited funds available for purchasing supplies needed to keep the rig in operation. While detecting contamination and measuring its extent are expensive, actual clean-up costs of contamination sites are enormous and may surpass funding levels needed to respond to any other pollution threat experienced in Michigan. ${ }^{39}$

The prospect of a monitoring program raises several questions. Who should finance the monitoring of the numerous aquifers, how many samples are necessary, and how often should monitoring occur? It hardly seems justified to suggest that private individuals pay potentially exorbitant costs for chemical analyses, yet the state and federal governments lack the personnel and budget to assume the responsibility. It is not realistic to expect possible polluters to monitor themselves and then remain unbiased while issuing reassuring public reports. Nevertheless, if standards are not developed, it will be 
extremely difficult for any agency to prevent polluters from contaminating groundwater supplies.

As with the federal government, the vast majority of the state governments appear to have fallen short in their attempts to protect groundwater supplies. The need is for well-defined legislation, adequate budgeting, knowledgeable personnel, and a will to have a comprehensive groundwater management program. To satisfy the need will require grassroots support and public acknowledgment of a groundwater crisis. Only then would it be likely that voluntary and legislative actions would unite to manage and protect our groundwater resources.

\section{Restoring Public Confidence}

Control of groundwater contamination from rural nonpoint sources such as agriculture requires site-specific investigations to determine the type and extent of toxic materials present and the characteristics of the surface and subsurface materials. Soil variations and aquifers can be very complex, especially in areas of glacial deposition. When chemicals enter the soil, their path is seldom readily known. Definitive statements should be avoided until input is received from geologists and groundwater hydrologists, soil scientists, environmental chemists, public health officials, and other technically trained specialists.

When used with appropriate caution, certain generalizations can assist rural land use planners in making decisions regarding the compatibility of agriculture and groundwater quality. Water or other fluids are keys to the movement of possible pollutants through the soil. Areas which receive regular irrigation or large amounts of rainfall or which have soluble rock materials or coarse-textured soils with water tables near the surface are prime candidates for groundwater problems. Contamination of water sources may also result from chemicals with low molecular weights and which do not biodegrade rapidly. Where these conditions occur in the same geographical area, extreme care should be exercised by planners in endorsing certain agricultural practices.

Even though a risk is always present, groundwater contamination attributed to agricultural land use is usually below levels that have been shown to cause disease. ${ }^{40}$ Because the threat to human health caused by agricultural practices is best classified as potential, agricultural use of groundwater recharge areas will continue in the future. Those who call for restrictions of all potentially hazardous land use demand that there be no risk to the groundwater, but in the United States the no-risk option is seldom viable. Although frequent policy review is desirable, production demands on our agricultural lands leave us little alternative but to continue their use. We already have the ability and the technology to reduce the pollution levels of our water. Improved cropping techniques, wiser application of nutrients and control chemicals, and better dissemination of information to farmers can dramatically restore or maintain public confidence in the nation's groundwater resources.

\section{FOOTNOTES}

1. Ian L. McHarg, Design with Nature (Garden City, N.Y.: Doubleday, 1971), pp. 103-61.

2. James T. B. Tripp and Adam B. Jaffe, "Preventing Groundwater Pollution: Towards a Coordinated Strategy to Protect Critical Recharge Zones," Harvard Environmental Law Review, vol. 3, no. 1 (May 1979), pp. 147.

3. Council on Environmental Quality, Environmental Quality: 12th Annual Report (Washington, D.C.: Government Printing Office, 1981), p. 33.

4. U.S. Department of Agriculture, Soil Conservation Service, Rural Clean Water Program: Environmental Impact Statement Draft (Washington, D.C.: Government Printing Office, 1978), p. 16.

5. George M. Browning, "Agricultural PollutionSources and Control," in Water Pollution: Control and Abatement, ed. Ted L. Willrich and N. William Hines (Ames: Iowa State U. Press, 1965), pp. 154-57.

6. B. A. Stewart et al., Control of Water Pollution from Cropland, U.S. Department of Agriculture Report no. ARS-H-5-1 (Washington, D.C.: Government Printing Office, 1975).

7. Herman Bouwer, Groundwater Hydrology (New York: McGraw-Hill, 1977), pp. 424-55.

8. W. C. Whitehead and H. Plate, "Best Management Practices for Fertilizer Use," in Best Management Practices for Agriculture and Silviculture, ed. Raymond C. Loehr et al. (Ann Arbor, Mich.: Ann Arbor Science Publishers, 1979), pp. 139-40.

9. Browning, op. cit.

10. Bouwer, op. cit.

11. Francis K. V. Leh and Richard K. C. Lak, Environment and Pollution: Sources, Health Effects, Monitoring, and Control (Springfield, Ill.: Charles C. Thomas, 1974), pp. 185-256.

12. Ibid.

13. Ibid.

14. Council on Environmental Quality, Environmental Quality: 9th Annual Report (Washington, D.C.: Government Printing Office, 1978), pp. 92-137.

15. Bouwer, op. cit.

16. K. S. LaFleur, G. A. Wojeck, and W. R. McGaskill, "Movement of Toxaphene and Fluometuron through Dunbar Soil to Underlying Groundwater," Journal of Environmental Quality, vol. 2, no. 4, (October/December 1973), pp. 515-18.

17. Browning, op. cit.

18. Bouwer, op. cit.

19. Stewart et al., op. cit., pp. 736-39.

20. R. G. Borman, Effects of a Cattle Feedlot on Ground-water Quality in the South Platte River Valley near Greeley, Colorado, U.S. Department of the Interior, Geological Survey, Water-Resources 
Investigations 80-83 (Lakewood, Col.: U.S. Department of the Interior, Geological Survey, 1981), pp. $1-78$.

21. L. N. Mielke and J. R. Ellis, "Nitrogen in Soil Cores and Groundwater under Abandoned Cattle Feedlots," Journal of Environmental Quality, vol. 5, no. 1 (January/March 1976), pp. 71-75.

22. Bouwer, op. cit.

23. Tripp and Jaffe, op. cit.

24. Merna Hurd, "The 208 Planning Approach to Ground-Water Protection-A Program Overview," Groundwater, vol. 17, no. 2 (March/April 1979), pp. 136-41.

25. Richard E. Bartelt, "State Ground-Water Protection Programs-A National Summary," Groundwater, vol. 17, no. 1 (January/February 1979), pp. 89-93.

26. Tripp and Jaffe, op, cit.

27. U.S., Congress, Safe Drinking Water Act, Pub.L. 93-523, S. 433, 42 USC 300h-3, Sec. 1424 (e), 93rd Cong., 16 December 1974.

28. Kenneth D. Schmidt, "The 208 Planning Approach to Ground-Water Protection-What is Wrong and What Can Be Done about It?" Groundwater, vol. 17, no. 2 (March/April 1979), pp. 148-53.

29. Hurd, op. cit.

30. David E. Burmaster and Robert H. Harris, "Groundwater Contamination: An Emerging
Threat," Technology Review, vol. 85, no. 5 (July 1982), p. 54

31. Bartelt, op. cit., p. 91, quoting Minnesota's environmental protection laws, chap. 115.

32. Bartelt, op. cit.

33. James W. Dawson, "State Ground-Water Protection Programs-Inadequate," Groundwater, vol. 17, no. 1 (January/February 1979), pp. 102-08.

34. Tripp and Jaffe, op. cit.

35. Personal correspondence from Steve Magee, Planner, City of Pompano Beach, Florida, 10 August 1982.

36. Memorandum, M. R. Stierheim (County Manager, Dade County, Florida), "Proposed Zoning Overlay Ordinance for the East Everglades Area of Critical Environmental Concern: Ordinance 81-122," 1 September 1981, p. 2.

37. James H. McDermott, "Ground-Water Quality Standards-Relevant," Groundwater, vol. 17, no. 1 (January/February 1979), pp. 35-58.

38. Tripp and Jaffe, op. cit.

39. Michigan Department of Natural Resources, “Department of Natural Resources Responds to Groundwater Problems," Environment Michigan (Lansing: Michigan Department of Natural Resources, 1981), pp. 1-2.

40. Raymond C. Loehr, Pollution Control for Agriculture (New York: Academic Press, 1977), p. 39.

Articles and book reviews appearing in Growth and Change are indexed in the Joumal of Economic Literature; Current Contents; Urban Affairs Abstracts; ABC POL SCI (Advance Bibliography of Contents: Political Science and Government); Magazines for Libraries; Librarians' Handbook; Guide to Periodicals in Education; BIZ-DEX, A Combined Retrospective Index to Book Reviews in Scholarly Journals, 1886-1974; United States Political Science Documents; Human Resources Abstracts; Sage Urban Studies Abstracts; Sage Public Administration Abstracts; and Real Estate Periodicals Index. 